\title{
CURRENT ESTIMATES AND PROBLEMS OF FINANCIAL LITERACY MEASUREMENT IN THE WORLD PRACTICE ${ }^{1}$
}

\section{E.Khudko}

In recent years, the problem of low level of financial literacy of the population has become evident in many countries. On the one hand, it leads to a slowdown in the retail financial segment, on the other hand, it could trigger instability in the financial market. In an attempt to solve this problem, authorities of different countries have begun to develop national strategies on improving financial literacy. The starting point for working on the strategy is assessing the current level of financial knowledge among the population. However, an overview of existing approaches to assessing financial literacy of the population shows that a variety of methods is used worldwide and research is conducted unsystematically, making it difficult to monitor financial literacy at the national level and make international comparative analysis.

Currently, a significant part of the world's population are not sufficiently involved in the financial sphere. In some cases, institutional factors may be at play, when certain territories and settlements are not covered by some financial services. However, the level of financial literacy of potential users of these services is of great importance for increasing the demand for the services. To make informed decisions about personal finance (on credit issues, money savings and investment, money transfers, cash-free payments, etc.), one should have some financial knowledge and understanding of basic concepts and rules of using financial products. Lack of knowledge about financial products and services and ways of interaction with service providers results in the fact that potential customers have no desire to use these opportunities, even if they have access to such services. Thus, increasing financial literacy should be seen as an important prerequisite for expanding the coverage of financial services. Having a certain level of financial literacy allows the consumer to consciously approach financial service use and to effectively identify best-quality market offers that are most appropriate to their personal needs.

It also needs to be realized that people with low levels of financial literacy cannot control their expenses, financial risks, are not able to predict financial implications of various force majeure events (job loss, illness, accident, etc.). This, in turn, has serious negative financial consequences not only at the micro level, but also at the macro level: financial losses of individual households turn into instability on a national scale or even crisis of the whole financial system. In addition, lack of knowledge about financial products, services, and technologies ultimately inhibit the development of the financial market's retail segment.

Understanding the relevance of the issue of increasing financial literacy of the population, authorities in many countries have begun to adopt national strategies and introduce educational programs on the subject. The starting

1 This article was prepared within the project "Promoting financial literacy of the population and the development of financial education in the Russian Federation." 
point for the development and implementation of these activities is assessing the current level of financial knowledge among the population, which would allow to identify the target groups of potential recipients of financial information and their current needs for financial services.

In each country, own studies are conducted that aim to determine the level of financial knowledge of the population both at the initial stage of national strategy development and following its implementation. However, this work is not sufficiently systematic - either in the coverage of population categories, methodological approaches to the assessment of results, or in monitoring frequency. This not only makes complex perception of the problem at the level of a single country difficult (in terms of defining/changing priorities and target groups), but also complicates cross-country comparisons. Some international organizations and large private analytics companies attempt to present their own assessment reviews of the levels of financial literacy in some countries. However, it is rather difficult, relying on these individual studies, to clearly identify the leader countries and, accordingly, to find the world's best practices which could be used as a reference for development and implementation of own strategy of improving financial literacy.

In particular, in 2010-2011, experts of the Organisation for Economic Co-operation and Development (OECD) and the International Network on Financial Education (INFE) jointly carried out a pilot research project on financial literacy. OECD characterizes financial literacy as a combination of financial knowledge, information, skills, approaches and behavioral patterns needed to make informed financial decisions and, ultimately, to improve citizens' financial well-being ${ }^{1}$. The project included an assessment of three components: financial knowledge, behavioral preferences and attitudes to personal finance ${ }^{2}$. Currently, the said study is perhaps the most detailed analysis of financial literacy, which also took into account social and demographic characteristics (gender, age, income, etc.). However, the project only covered 14 countries $^{3}$. The study did not aim to make a ranking of countries by level of financial literacy but was focused on specifics of financial behaviour and attitudes to financial planning among different categories of the population.

The study of financial literacy was built on the analysis of respondents' answers to eight questions from different financial areas and of different difficulty levels (basic financial calculations, time-value of money, the nature of compound interest, definition of inflation, interest paid on a loan, calculation of interest plus principle, risk and return, diversification of investments), but at the same time not requiring any specific professional knowledge. Respondents with high level of financial knowledge were defined as those who were able to give correct answers to 6 or more questions. The study revealed serious lack of financial knowledge among quite a large proportion of the population: in none of the countries surveyed, the share of respondents who had answered 6 or more questions did not exceed $70 \%$.

1 Messy F.-A. Role of financial education for pension: relevance of workplace delivery // OECD Financial Affairs Division, Seminar on Financial education and retirement savings Toward Securing a Comfortable Retirement Malaysia, 17-18 September 2013.

2 Atkinson A., Messy F.-A. Measuring Financial Literacy: Results of the OECD / International Network on Financial Education (INFE) Pilot Study // OECD Working Papers on Finance, Insurance and Private Pensions, No. 15, 2012, OECD Publishing.

3 Albania, Armenia, British Virgin Islands, United Kingdom, Hungary, Germany, Ireland, Malaysia, Norway, Peru, Poland, Czech Republic, Estonia, South Africa. 
The second part of the survey, which dealt with characteristics of financial behaviour, aimed at learning how a respondent will behave in a given situation when making a purchase, paying a bill, planning the budget, saving or borrowing money. In many of the countries surveyed, the respondents' financial behavior was recognized as positive in less than half of the time.

Finally, attitudes to finances and financial preferences were examined, which are also important elements of financial literacy. The questions primary concerned long-term financial plans and saving money. However, there was a big gap between the countries in this regard.

Table 1 shows the percentage of high scores for each component of financial literacy. The study demonstrated that the same set of questions can well be used to analyze financial literacy in different countries and population categories.

Table 1

HIGH SCORE ON EACH OF THE FINANCIAL LITERACY COMPONENTS (\%)

\begin{tabular}{|l|c|c|c|}
\hline & $\begin{array}{c}\text { High knowledge } \\
\text { score }\end{array}$ & $\begin{array}{c}\text { High behaviour } \\
\text { score }\end{array}$ & $\begin{array}{c}\text { High attitude } \\
\text { score }\end{array}$ \\
\hline Albania & 45 & 39 & 69 \\
\hline Armenia & 46 & 41 & 11 \\
\hline Czech Republic & 57 & 48 & 62 \\
\hline Estonia & 61 & 27 & 46 \\
\hline Germany & 58 & 67 & 63 \\
\hline Hungary & 69 & 38 & 69 \\
\hline Ireland & 60 & 57 & 49 \\
\hline Malaysia & 51 & 67 & 53 \\
\hline Norway & 40 & 59 & 57 \\
\hline Peru & 41 & 60 & 71 \\
\hline Poland & 49 & 43 & 27 \\
\hline South Africa & 33 & 51 & 54 \\
\hline United Kingdom & 53 & 71 & 49 \\
\hline British Virgin Islands & 57 & & 67 \\
\hline
\end{tabular}

Source: Atkinson A., Messy F.-A. Measuring Financial Literacy: Results of the OECD / International Network on Financial Education (INFE) Pilot Study // OECD Working Papers on Finance, Insurance and Private Pensions, No. 15, 2012, OECD Publishing.

The next interesting work is the World Bank's attempt to measure the financial literacy of the population. The Bank, together with OECD, has developed a methodology for analyzing the level of financial knowledge (financial knowledge score). It should be emphasized that the notions of financial knowledge and financial literacy are not synonymous. Being financially literate implies more than just having the knowledge about financial issues and phenomena. It also requires skills of practical financial operations, being able to navigate in the flow of financial information, minimize the possibility of making mistakes, all of which together would contribute to the improvement of the current and long-term financial well-being.

Anyway, the financial knowledge score is based on questions concerning six thematic areas: definition of inflation, essence of interest rates, compound interest scheme, theory of money, diversification of risks, goals of insurance. The indicator is calculated by summing up the percentage of respondents who gave correct answers to each of these questions (estimated in the range of 0 to 3 units). This work began in 2011, but the study of countries is carried 
out unsystematically. Over the past five years, according to the World Bank, only 12 countries were surveyed using this method (Table 2).

Table 2

ASSESSMENT OF THE LEVEL OF FINANCIAL KNOWLEDGE IN DIFFERENT COUNTRIES (RANGING FROM 0 TO 3 UNITS)

\begin{tabular}{|l|c|c|c|}
\hline & 2011 & 2012 & 2013 \\
\hline Albania & 1,9 & & \\
\hline Columbia & & 1,7 & \\
\hline Jamaica & & 1,8 & \\
\hline Korea & & 2,0 & \\
\hline Lebanon & & 2,2 & \\
\hline Mexico & & 1,8 & \\
\hline Mongolia & & 2,0 & \\
\hline New Zealand & & 1,9 & \\
\hline Serbia & & 1,5 & \\
\hline Tajikistan & & 1,6 & \\
\hline Turkey & & 2,2 & \\
\hline Uruguay & & & \\
\hline
\end{tabular}

Source: World Bank, "G20 Financial Inclusion Indicators".

Among the World Bank studies on the issue of financial literacy, one can also mention the review "Global Survey on Consumer Protection and Financial Literacy - Oversight Frameworks and Practices in 114 Economies" published in 2014. Yet, it mainly concerned institutional mechanisms of implementation of financial education programs and adaptation of the legal framework.

In 2015, the international rating agency Standard \& Poor's presented their cross-country review of financial literacy (The Standard \& Poor's Ratings Services Global Financial Literacy Survey). During its creation, some approaches were borrowed from the studies carried out by OECD, INFE, the World Bank, as well as from individual national strategies. In the review, S\&P made an attempt to introduce the first global instrument to measure financial literacy. The study involved more than 150 thousand adults (aged 15 years and older) from more than 140 countries. The agency suggested measuring financial literacy based on questions on understanding four basic financial concepts: numeracy (interest), compound interest, inflation, and risk diversification. According to the methodology of the study, the respondent is considered financially literate if he or she gave the right answer to at least three out of four questions.

The overall result of the study on the countries surveyed is that, on average, only one out of three respondents is financially literate, although, of course, the spread across countries is quite significant. It should be noted that the low level of financial knowledge is observed not only in developing economies but also among certain population categories in some quite developed countries (Table 3). Another important result of the study is that high level of financial literacy can be observed both among respondents with high income and low income, and the opposite is true - although, of course, the share of financially literate citizens in all countries is on average somewhat higher in the group of respondents with higher income. The questions that turned out to be most understandable for respondents were those related to inflation and simple mathematical calculations, whereas the most difficult one was about diversification of risks. 
Table 3

ASSESSMENT OF FINANCIAL LITERACY IN DIFFERENT COUNTRIES

\begin{tabular}{|c|c|c|c|}
\hline & \multirow[b]{2}{*}{$\begin{array}{l}\text { At least } 3 \text { out of } 4 \\
\text { answers correct } \\
\text { (\% adults) }\end{array}$} & \multicolumn{2}{|c|}{ Including } \\
\hline & & $\begin{array}{l}\text { adults living in } \\
\text { the richest } 60 \% \text { of } \\
\text { households, } \%\end{array}$ & $\begin{array}{c}\text { adults living in the } \\
\text { poorest } 40 \% \text { of } \\
\text { households, } \%\end{array}$ \\
\hline & $65-71$ & & \\
\hline Sweden & 71 & 76 & 64 \\
\hline Norway & 71 & 74 & 67 \\
\hline Denmark & 71 & 75 & 65 \\
\hline Canada & 68 & 73 & 61 \\
\hline Israel & 68 & 72 & 63 \\
\hline United Kingdom & 67 & 70 & 63 \\
\hline Germany & 66 & 73 & 55 \\
\hline \multirow[t]{2}{*}{ Netherlands } & 66 & 71 & 60 \\
\hline & $55-64$ & & \\
\hline Australia & 64 & 73 & 50 \\
\hline Finland & 63 & 70 & 53 \\
\hline New Zealand & 61 & 67 & 53 \\
\hline Singapore & 59 & 62 & 56 \\
\hline Czech Republic & 58 & 61 & 55 \\
\hline USA & 57 & 64 & 47 \\
\hline Sweden & 57 & 62 & 49 \\
\hline Belgium & 55 & 59 & 50 \\
\hline \multirow[t]{2}{*}{ Ireland } & 55 & 64 & 41 \\
\hline & $45-54$ & & \\
\hline Hungary & 54 & 52 & 56 \\
\hline Estonia & 54 & 61 & 45 \\
\hline Austria & 53 & 59 & 44 \\
\hline France & 52 & 55 & 47 \\
\hline Spain & 49 & 54 & 43 \\
\hline Slovakia & 48 & 53 & 41 \\
\hline Latvia & 48 & 52 & 43 \\
\hline \multirow[t]{2}{*}{ Greece } & 45 & 49 & 38 \\
\hline & $35-45$ & & \\
\hline Slovenia & 44 & 53 & 31 \\
\hline Japan & 43 & 45 & 40 \\
\hline Poland & 42 & 44 & 40 \\
\hline South Africa & 42 & 45 & 37 \\
\hline Chile & 41 & 43 & 38 \\
\hline Turkmenistan & 41 & 41 & 41 \\
\hline Kazakhstan & 40 & 42 & 36 \\
\hline Ukraine & 40 & 43 & 35 \\
\hline Lithuania & 39 & 45 & 30 \\
\hline Russia & 38 & 42 & 33 \\
\hline Belarus & 38 & 43 & 30 \\
\hline Italy & 37 & 44 & 27 \\
\hline Azerbaijan & 36 & 37 & 35 \\
\hline \multirow[t]{2}{*}{ Brazil } & 35 & 38 & 29 \\
\hline & $25-34$ & & \\
\hline Mexico & 32 & 36 & 26 \\
\hline Korea & 33 & 39 & 25 \\
\hline
\end{tabular}


Table 3, cont'd

\begin{tabular}{|l|c|c|c|}
\hline & $\begin{array}{c}\text { At least } 3 \text { out of } 4 \\
\text { answers correct } \\
\text { (\% adults) }\end{array}$ & $\begin{array}{c}\text { Including } \\
\text { the richest 60\% of } \\
\text { households, \% }\end{array}$ & $\begin{array}{c}\text { adults living in the } \\
\text { poorest 40\% of } \\
\text { households, \% }\end{array}$ \\
\hline Georgia & 30 & 32 & 26 \\
\hline China & 28 & 32 & 22 \\
\hline Argentina & 28 & 33 & 21 \\
\hline Moldova & 27 & 31 & 23 \\
\hline Portugal & 26 & 35 & 25 \\
\hline Venezuela & 25 & 25 & 20 \\
\hline India & $0-24$ & 26 & 13 \\
\hline Turkey & 24 & 26 & 15 \\
\hline Uzbekistan & 24 & 25 & 17 \\
\hline Kyrgyzstan & 21 & 21 & 15 \\
\hline Armenia & 19 & 19 & 20 \\
\hline Tajikistan & 18 & 18 & \\
\hline
\end{tabular}

Source: The Standard \& Poor's Ratings Services Global Financial Literacy Survey.

Table 4

SNAPSHOT OF PERFORMANCE IN FINANCIAL LITERACY AMONG SCHOOLCHILDREN, OBTAINED IN THE FRAMEWORK OF PISA 2012 PROJECT

\begin{tabular}{|c|c|c|c|}
\hline & $\begin{array}{l}\text { Mean } \\
\text { score }\end{array}$ & $\begin{array}{c}\text { Share of lowest } \\
\text { performers } \\
\text { (Level } 1 \text { or below), \% }\end{array}$ & $\begin{array}{c}\text { Share of top } \\
\text { performers } \\
\text { (Level } 5 \text { or above), \% }\end{array}$ \\
\hline Shanghai-China & 603 & 1,6 & 42,6 \\
\hline $\begin{array}{l}\text { Flemish Community } \\
\text { (Belgium) }\end{array}$ & 541 & 8,7 & 19,7 \\
\hline Estonia & 529 & 5,3 & 11,3 \\
\hline Australia & 526 & 10,4 & 15,9 \\
\hline New Zealand & 520 & 16,1 & 19,3 \\
\hline Czech Republic & 513 & 10,1 & 9,9 \\
\hline Poland & 510 & 9,8 & 7,2 \\
\hline Latvia & 501 & 9,7 & 4,6 \\
\hline OECD average-13 & 500 & 15,3 & 9,7 \\
\hline United States & 492 & 17,8 & 9,4 \\
\hline Russian Federation & 486 & 16,7 & 4,3 \\
\hline France & 486 & 19,4 & 8,1 \\
\hline Slovenia & 485 & 17,6 & 5,8 \\
\hline Spain & 484 & 16,5 & 3,8 \\
\hline Croatia & 480 & 16,5 & 3,8 \\
\hline Israel & 476 & 23,0 & 8,5 \\
\hline Slovak Republic & 470 & 22,8 & 5,7 \\
\hline Italy & 466 & 21,7 & 2,1 \\
\hline Columbia & 379 & 56,5 & 0,7 \\
\hline
\end{tabular}

Source: Organization for Economic Co-operation and Development (OECD). PISA 2012 Results: Students and Money: Financial Literacy Skills for the 21st Century // Volume VI, OECD Publishing. 
OECD experts also carried out an international study evaluating financial literacy among schoolchildren - PISA $2012^{1}$, which estimated financial knowledge and practical skills of taking financial decision (PISA test) among pupils of 15 years of age. The review covered 29 thousand schoolchildren from 18 countries, which were offered the following types of questions:

- questions from four areas of financial knowledge: the concept of money, aspects of transactions, financial planning and management, risk and return, financial environment;

- questions on four types of financial activities: searching for financial information, analysis of financial information, studying different financial issues, using financial knowledge and skills;

- questions in four specific situations in relation to: education and work, home and family, the respondent personally and society as a whole.

The study results demonstrated a wide range of values among countries and a large gap between schoolchildren's levels of knowledge within one country (students from China and Belgium scored the maximum number of points) (Table 4). However, the results were similar to those of the comparable studies of the adult population. This suggests that low levels of financial literacy in secondary school (in the absence of financial education in the future) has a significant influence on people's subsequent operations with personal finance. A second similar study of financial literacy among schoolchildren was carried out in 2015; its results will be published at the end of 2016.

The review of approaches to assessing the level of financial literacy showed that, firstly, there are no established methods at the moment that have proven effective in the world practice, even though several international organizations and private analytical companies work in this direction. Secondly, even within the framework of existing methods, the monitoring of financial literacy is carried out unsystematically and/or is characterized by incomplete coverage of countries, which complicates the analysis of the problem on a global scale and the development of effective national strategies in this field.

However, despite the differences in methods of measuring financial litera$c y$, the above studies state the lack of financial knowledge among the population even in many developed countries. Thus it can be argued that all the authorities' efforts to actively engage citizens in the financial sector without increasing their financial literacy either will be ineffective or will lead to negative consequences for the entire economy.

1 Organization for Economic Co-operation and Development (OECD). PISA 2012 Results: Students and Money: Financial Literacy Skills for the 21st Century // Volume VI, OECD Publishing. 


\section{STATE PROPERTY MANAGEMENT: STATISTICAL PORTRAIT NOVELTIES}

A new indicator framework for the performance measurement of state property management was adopted early last year. Basic characteristics of state property and of economic entities that are in state ownership have been presented on the basis of the initial data gathered from the framework. Transition to providing data in terms of legal forms, which was not the case under the old indicator framework for public sector monitoring, as well as a special focus on property (real estate, land, stakes (interest) of any size) given the value and liquidity thereof is the main novelty that the new framework offers.

The data obtained from the indicator framework for the performance measurement of state property management were first published in the last spring. The framework was adopted by Russian Government's Executive Order No. 72 of 29 January 2015 in replacement for a indicator framework for public sector monitoring that the Federal State Statistics Service (Rosstat) employed since the start of the 2000s pursuant to Russian Government's Executive Order No. 1 of 4 January 1999 (as amended on 30 December 2002). Serious changes have taken place with regard to the population of economic entities that are monitored with the purpose of assembling of statistical data (Table 1).

With great generality of the public sector in the old definition and in the new array of indicators, one cannot but note the absence of public sector's essential element such as business entities in which public sector business entities held a stake (interest) of more than $50 \%$, which limits the stakeholding comparison with the data for the previous years (Table 2).

According to the data obtained from the new framework, the number of economic entities that are in state ownership totalled approximately 65,600 by the start of 2016, which is 1,000 above the public sector monitoring data released two years ago, but it is about 540 below the number reported in the mid-2013.

Note an increase in comparable categories of economic entities compared with the most recent data of the public sector monitoring as of the mid-2014, the number of government agencies increased about 2,500 (or 4.6\%) while the number of state unitary enterprises (SUEs) was up about 50 (or 1.1\%), and the number of government entities by the start of 2016 was found to even outnumber the number seen three years ago. It is difficult to make any conclusions about business entities because the old and the new frameworks are incompatible in terms of this category. What is obvious is that their total number (about 3,900 ) by the start of 2016 outnumbered the number $(3,500)$ of business entities in which the state held a controlling stake (interest) by the start of 2013 .

1 The most recent public sector development bulletin covered the period between January and September 2014, but the semi-annual data as of 1 July 2014 are quite useful for a medium term analysis. 